\title{
Family Planning as a Human Right: Knowledge for Better Decision-making by Cuban Adolescents
}

\section{Sara Más}

Translated from the Spanish (original title, Saber para decidir mejor) and reprinted from Revista Mujeres, July 12, 2018. Original available at: http://www.mujeres.co.cu/art.php?NzMwNg

Family as well as individual behavior play an important part in the decision to have a child [in Cuba], according to research from the University of Havana's Center for Demographic Studies (CEDEM).

Sexual initiation often takes place without contraception, said CEDEM researcher, Maydee Vázquez, during a recent panel entitled Family planning and reproductive rights from the perspectives of demographics and sexuality. The gathering was convened on July 9 by CEDEM, the Population Studies Network and the Cuban Society for Multidisciplinary Sexuality Studies (SOCUMES), to mark World Population Day (July 11), whose theme this year was Family Planning is a Human Right.

Several studies [in Cuba] have revealed that many women are unaware of their monthly fertile period, never mention male sterilization and rarely speak of emergency contraception. In addition, contraceptive usage is sporadic or interrupted, a behavior pattern associated with fluctuating understanding of their use and intermittent market availability.

Research also identifies deficiencies in sex education and awareness, as well as sexual and reproductive health services that focus almost exclusively on women, thus limiting opportunities for involving men, who may also be participants in the decisionmaking process.

Vázquez noted that adolescents often copy the reproductive behavior of their elders and women are the main ones who decide on family planning methods. These may be used irregularly, and when they fails, women resort to abortion or decide to have the child.

Thus, in the arena of gender and sexual rights [in Cuba], she described the pending challenges as: irregular contraceptive use, predominance of female contraceptive methods, higher rate of female sterilization compared to male, low acceptability and promotion of the latter, and the descending mean age of sexual initiation in adolescent girls.

A case study of pregnant adolescents in San Miguel del Padrón Municipality in Havana found that these young women tended to repeat familial patterns, in which mothers and grandmothers were also adolescent mothers, and were ill informed about family planning methods.

[Adolescents] may protect themselves in their first sexual encounter, but then use contraception only intermittently, and it's not a theme discussed by their families, which also often have misconceptions about family planning methods, commented CEDEM researcher Gabriela Dujarric. The majority of adolescents interviewed [by CEDEM researchers] had had at least one abortion and it was clear that often their mothers had been involved in decisions about continuing or interrupting the pregnancy.

What's more, those who decided to continue their pregnancy at that time distanced themselves from the study, some withdrawing completely, also avoiding activities such as parties, games and excursions, many of which were the setting for the relations that led to their pregnancy. Rather, in such cases, watching television, and chatting with partner and family become the routine for them, and they tend to leave school to take on domestic tasks and child care. Thus, commented Dujarric, they suddenly go from a girlfriend/boyfriend relationship to one that calls for child-rearing, with the resulting loss of outside interests, in a scenario that keeps them from recognizing the situation in which they find themselves.

Family planning is now
recognized as a right
for women and families,
although education is still
not where it needs to be...

The family transmits reproductive values, from grandmother to mother to daughter, and with vague communication about sexuality and little educational oversight. [In this context],

Dr Gabino A. Alessandrini noted: "Family planning is now recognized as a right for women and families," although education [in that respect] is still not where it needs to be, and adolescents still get most of their information from their peers. He reflected that such education is the responsibility of the schools and public health system, which should accompany them as subjects with rights and transformation agents in their journey to autonomy, so that they can realize their life goals.

The gathering was dedicated to Professor Sonia Catasús Cervera, an outstanding demographer and population researcher at CEDEM, who died in June. Catasús carried out landmark studies for Cuba and Latin America, notably research on marriage and families. Colleagues and friends praised her scholarship, human qualities and approach to life, as well as her teaching and professional practice. $-1 /$ -

Correspondence: Sara Más, farias@enet.cu 